\title{
PENGARUH PEMBERIAN MONOSODIUM GLUTAMAT (MSG) PADA TIKUS JANTAN (Rattus Norvegicus) TERHADAP FSH DAN LH
}

\author{
Zulkarnain Edward \\ Bagian Biokimia Fakultas Kedokteran Universitas Andalas \\ E-mail : zulkarnain.edward@yahoo.co.id
}

\section{Abstrak}

Kemajuan teknologi informasi membawa dampak terhadap perubahan gaya hidup masyarakat, termasuk perubahan pola konsumsi makanan yang lebih banyak mengkonsumsi jenis makanan cepat saji, makanan kemasan dan makanan awetan yang belakangan ini semakin banyak dijual dipasar tradisional dan swalayan. Penggunaan bahan tambahan makanan sering dijumpai, salah satunya adalah bahan penyedap yang banyak sekali digunakan seperti senyawa L-asam glutamat yang digunakan dalam bentuk garam yaitu monosodium glutamat (MSG). Berbagai merk dagang MSG telah dikenal dimasyarakat secara luas seperti ajinomoto, vetsin, micin, sasa, miwon dan sebagainya.

MSG adalah garam monosodium dengan asam glutamat yang sering digunakan sebagai bahan penyedap masakan untuk merangsang selera makan. Pemberian MSG mengakibatkan gangguan hormonal pada hewan coba, ion glutamat dalam sirkulasi portal akan mempengaruhi hipotalamus dalam memproduksi GnRH yang selanjutnya akan mengganggu hipofise anterior dalam memproduksi FSH dan LH. Fungsi FSH adalah untuk bekerja pada tubulus seminiferus terutama pada sel sertoli untuk meningkatkan spermatogenesis, sedangkan LH berfungsi pada sel Leydig untuk mengatur sekresi testosteron.

Penelitian ini bersifat eksperimen dengan rancangan post only group design. Penelitian dilakukan di laboratorium Biologi dan laboratorium Biokimia Fakultas Kedokteran Unand Padang dari tanggal 20 Desember 2009 sampai 30 Februari 2010. Populasi adalah tikus putih jantan strain Jepang (Rattus norvegicus) yang berasal dari laboratorium Fakultas Matematika dan Ilmu Pengetahuan Alam Unand. Sampel berjumlah 20 ekor dibagi atas 4 kelompok dengan satu kelompok kontrol dan tiga kelompok perlakuan. Dosis MSG yang digunakan yaitu P1= 4800 $\mathrm{mg} / \mathrm{kgbb} / \mathrm{hari}, \mathrm{P} 2=7200 \mathrm{mg} / \mathrm{kgbb} /$ hari dan P3= $9600 \mathrm{mg} / \mathrm{kgbb} /$ hari diberikan peroral sebanyak dua siklus epitel seminiferus. Analisa dengan uji Anova dengan derajat kepercayaan 95\% dan jika bermakna dilanjutkan dengan uji Multiple Comparissons jenis Bonferroni.

Hasil penelitian yang diperoleh bahwa pemberian MSG dengan dosis 4800 $\mathrm{mg} / \mathrm{kgbb} / \mathrm{hari}, 7200 \mathrm{mg} / \mathrm{kgbb} / \mathrm{hari}$ dan $9600 \mathrm{mg} / \mathrm{kgbb} / \mathrm{hari}$ menunjukkan pengaruh yang bermakna terhadap penurunan kadar FSH $(p=0,000)$ dan LH $(p=0,000)$, namun pada uji Multiple Comparissons Bonferroni didapatkan antar kelompok pada FSH belum menunjukan pengaruh yang bermakna $(\mathrm{p}>0,05)$ sedangkan pada LH antar kelompok perlakuan, antara P1, P2 tidak didapatkan perbedaan yang 
bermakna $(\mathrm{p}>0,05), \mathrm{P} 1$ dan P3 didapatkan perbedaan yang bermakna $(\mathrm{p}<0,05)$ dan $\mathrm{P} 2$ dengan $\mathrm{P} 3$ didapatkan perbedaan yang bermakna $(\mathrm{p}<0,05)$.

Penelitian ini menyimpulkan bahwa pemberian MSG terhadap tikus jantan dapat menurunkan kadar FSH dan LH. Disarankan untuk dilakukan penelitian lanjutan untuk mendapatkan dosis minimal yang dapat memberikan perubahan kadar FSH dan LH.

Kata kunci : MSG, FSH, LH

\section{Abstract}

The progress of information and technology gave the influence in society and life styles, included the change of goods and provision system, which become more prefered to fast food, meal packaged and preserved, then firmly sells and found in traditional market and swalayan. The continously use of additional substance firmly seems everywhere, one of them is something used as flavoring, L-Glutamat acid which used in a mineral salt that is Monosodium Glutamat (MSG). Many kinds of MSG brand known by people as ajinomoto, vetsin, micin, sasa, miwon, etc.

MSG is a mineral salt of monosodium with glutamat acid that firmly used as the food flavoring for appetizer. The distribution of MSG causing the hormonal interference for the animal trial, which the glutamat ion in portal sirculation will effect the hipotalamus in producting the GnRH which were next would effected the anterior hypofise in producting the FSH and LH. The FSH function is to do working for seminiferus tubular espeially for sertoli cells to increase the spermatogenesis, then LH functioned to Leydig to control the testosteron secretion.

This research experimently done with post only group design, take place in Biology Laboratorium and Biochemistry, Faculty of Medicine Andalas University in December 20th, 2009 until Februari 30th, 2010. The population is the white rat strain Japan (Rattus Norvegicus) taken from Faculty of Mathematic and Natural Sciences Andalas University. There are 20 samples devided into 4 groups with 1 group controller and three treated groups. $\mathrm{P} 1=4800 \mathrm{mg} / \mathrm{kgbw} / \mathrm{day}, \mathrm{P} 2=7200$ $\mathrm{mg} / \mathrm{kgbw} /$ day and $\mathrm{P} 3=9600 \mathrm{mg} / \mathrm{kgbw} /$ day used as MSG dose, given orally about two seminiferus epitel cycles. The analysis by Anova test with $95 \%$ of trust and if there would sense of in meaning, continued with Multiple Comparissons test, kind of Bonferroni.

The result of the research taken that the MSG given with $4800 \mathrm{mg} / \mathrm{kgbw} / \mathrm{day}$, $7200 \mathrm{mg} / \mathrm{kgbw} / \mathrm{day}$ and $9600 \mathrm{mg} / \mathrm{kgbw} /$ day showed the significant effect to FSH $(\mathrm{p}=0,000)$ and $\mathrm{LH}(\mathrm{p}=0,000)$, but for the Multiple Comparissons Bonferroni test between groups in FSH, there were not yet have the meaning in effect $(p>0,05)$ then to LH for the treated groups, between P1, P2 there were not any significant differences $(p>0,05) \mathrm{P} 1$ and $\mathrm{P} 3$ got the significant differenciates $(\mathrm{p}<0,05)$ and $\mathrm{P} 2$ with P3 got the significant effect $(p<0,05)$.

The research concluded that the MSG given for the male rat could decrease the FSH and LH. Suggested to do the following research to find the minimal dose change level FSH and LH.

Key word : MSG, FSH, LH 


\section{Pendahuluan}

Perubahan gaya hidup juga menyebabkan terjadinya perubahan pola konsumsi makanan, dimana makanan yang paling digemari adalah makanan yang cepat saji, dalam kemasan dan makanan yang diawetkan. Sebagian besar makanan tersebut diatas mengandung penyedap untuk merangsang selera makan. Salah satu penyedap makanan yang telah dikenal oleh masyarakat adalah garam monosodium glutamat (MSG) dalam berbagai macam merk dagang. Di Indonesia MSG dibuat dari berbagai tetes tebu (molases) dengan cara fermentasi oleh bakteri Micrococcus glutamicus. ${ }^{(1,2)}$ Pemakaian MSG di Amerika Serikat sudah dikenal sejak tahun $1947 .^{(3)}$ Pemakaian MSG dosis besar dan lama akan memberikan efek samping yang salah satunya dapat mengakibatkan gangguan hormonal dimana ion glutamat mempengaruhi produksi GnRH dari hipotalamus dan kerusakan pada sel neuron hipotalamus. ${ }^{(4)}$ Asam glutamat dapat dirubah menjadi asam keto glutarat dalam hati, tapi apabila pemberian glutamat melebihi kemampuan hati dalam metabolismenya menyebabkan peningkatan asam glutamat dalam darah. ${ }^{(5)}$ Gangguan GnRH ini menyebabkan ganguan kelenjar hipofise anterior untuk memproduksi FSH dan LH. FSH berfungsi untuk pematangan folikel pada wanita dan proses spermatogenesis serta pemeliharaan spermatozoa pada pria dalam sel Sertoli. Sel Sertoli berfungsi juga dalam mempersiapkan laktat, transferrin dan androgen binding protein untuk metabolisme sel germinal. ${ }^{(6)}$ Sedangkan hormon LH berfungsi untuk merangsang sel Leydig pada testis dalam pembentukan hormon testosteron.

Bila mencit betina percobaan dikawinkan dengan mencit jantan normal, maka jumlah kehamilan dan jumlah anak berkurang secara ber- makna. Mencit jantan yang diberi MSG setelah dewasa menunjukkan tandatanda penurunan fertilitas antara lain berkurangnya berat testis, undenscended testis dan berat hipofisis berkurang. ${ }^{(7)}$

Penyuntikan MSG subkutan pada anak tikus jantan dan betina yang baru dilahirkan dengan dosis 2200 sampai $4200 \mathrm{mg} / \mathrm{kg} \mathrm{BB} /$ hari selama 12 hari maka setelah dewasa terjadi pengurangan berat dari organ endokrin, penurunan hormon pertumbuhan, berkurangnya berat ovarium dan terhentinya pertumbuhan folikel sehingga menjadi atresia. ${ }^{(8)}$

Karena adanya beberapa gangguan pada sistim reproduksi maka perlu dipelajari efek MSG ini terhadap kadar FSH dan LH pada tikus jantan (Rattus Norvegicus).

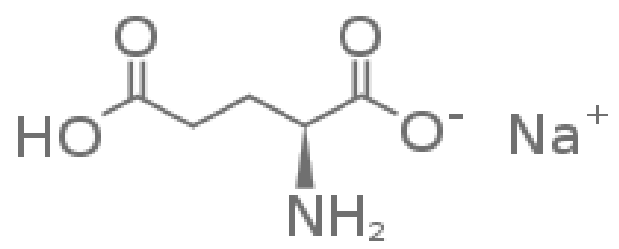

Gambar 1. Struktur senyawa Monosodium Glutamat

Nama menurut IUPAC : Sodium (2S)2-amino-5-hydroxy-5-oxo-pentanoate Rumus Molekul : $\mathrm{C}_{5} \mathrm{H}_{8} \mathrm{NNaO}_{4}$ Berat Molekul : $169,111 \mathrm{~g} / \mathrm{mol}$ Titik Lebur $\quad: 225{ }^{\circ} \mathrm{C}$ Kelarutan dalam air $: 74 \mathrm{~g} / 100 \mathrm{ml}$.

\section{METODOLOGI}

Alat dan Bahan

Penelitian ini merupakan penelitian eksperimental dengan rancangan Postest Only Group Design menggunakan 20 ekor tikus putih jantan strain Jepang (Rattus norvegicus) yang berasal dari laboratorium Fakultas Matematika dan Ilmu Pengetahuan Alam Unand yang berumur antara 2,5 - 3 bulan. Garam monosodium glutamat yang 
digunakan diperoleh di pasaran bebas dengan merek dagang Ajinomoto produksi PT. Ajinomoto Indonesia. Bubuk MSG berupa kristal putih mengandung $99 \%$ monosodium glutamat dan terbungkus rapi dalam kantong plastik tertutup. Alat-alat yang digunakan antara lain gamma counter, sonde lambung, Kit FSH dan LH, timbangan MSG (Precision Balancer Roller Smith) dan alat-alat gelas.

\section{Prosedur}

Tikus jantan sebanyak 20 ekor dipelihara lebih dulu selama satu minggu untuk adaptasi lingkungan kemudian dibagi dalam 4 kelompok dimana satu kelompok untuk kontrol dan tiga kelompok perlakuan. Kelompok kontrol diberi makanan dasar seperti biasa, sedangkan untuk kelompok perlakuan diberikan larutan garam monosodim glutamat sebagai berikut :

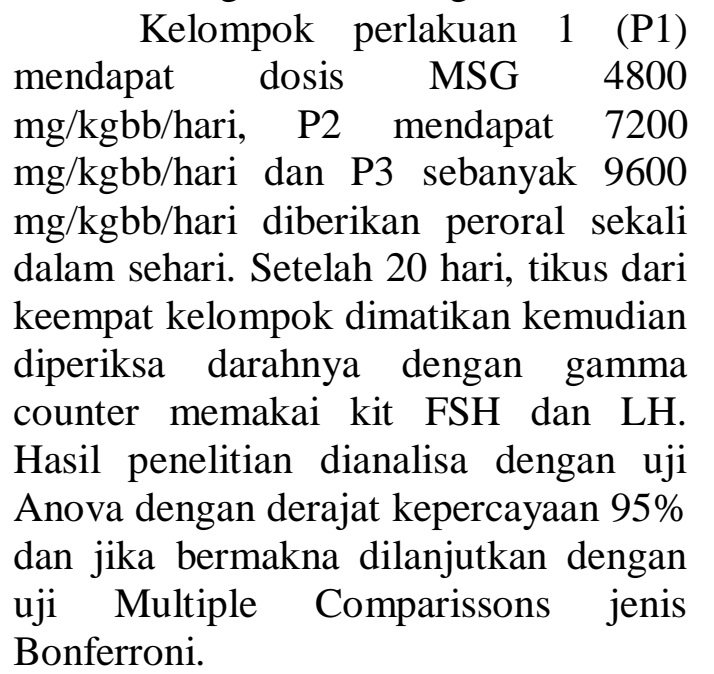

\section{HASIL DAN DISKUSI}

Pengaruh pemberian MSG terhadap kadar FSH dapat dilihat pada tabel 1 berikut :
Tabel 1. Kadar rata-rata FSH tikus jantan pada kelompok kontrol dan perlakuan

\begin{tabular}{lcc}
\hline Kelompok & $\begin{array}{c}\text { Kadar FSH } \\
(\mathbf{m I U} / \mathbf{m l}) \\
\text { Mean } \pm \text { SD }\end{array}$ & p \\
\hline Kontrol & $0.256 \pm$ & \\
& 0.006 & \\
P1 & $0.214 \pm$ & 0,000 \\
& 0.018 & \\
P2 & $0.197 \pm$ & \\
& 0.014 & \\
P3 & $0.191 \pm$ & \\
& 0.009 & \\
\hline
\end{tabular}

Dari tabel 1. diperoleh bahwa pemberian MSG dengan dosis 4800 $\mathrm{mg} / \mathrm{kgbb} / \mathrm{hari}, 7200 \mathrm{mg} / \mathrm{kgbb} / \mathrm{hari}$ dan $9600 \mathrm{mg} / \mathrm{kgbb} / \mathrm{hari}$ menunjukkan pengaruh yang bermakna terhadap kontrol dalam penurunan kadar FSH $(\mathrm{p}=0,000)$.

\section{Tabel 2. Hasil Uji Multiple Comparisons terhadap FSH}

\begin{tabular}{lcc}
\hline \multicolumn{1}{c}{ Kelompok } & $\begin{array}{c}\text { Perbedaan } \\
\text { Mean }\end{array}$ & p \\
\hline $\begin{array}{l}\text { Kontrol } \\
\text { dengan P1 }\end{array}$ & 0,042000 & 0,000 \\
$\begin{array}{l}\text { Kontrol } \\
\text { dengan P2 }\end{array}$ & 0,058400 & 0,000 \\
Kontrol & & \\
dengan P3 & 0,064400 & 0,000 \\
P1 dengan P2 & 0,016400 & 0,214 \\
P1 dengan P3 & 0,022400 & 0,057 \\
P2 dengan P3 & 0,006000 & 0,877 \\
\hline
\end{tabular}

Dari tabel 2 diatas dengan uji Multiple Comparisons Bonferroni didapatkan antar kelompok perlakuan pada FSH tidak menunjukan pengaruh yang bermakna $(p>0,05)$. 
Pengaruh pemberian MSG terhadap Dari tabel 4 diatas dengan uji Multiple kadar LH dapat dilihat pada tabel 3 Comparissons Bonferroni didapatkan berikut :

Tabel 3. Kadar rata-rata LH tikus pada LH antar kelompok perlakuan, antara P1 dengan P2 tidak didapatkan jantan pada kelompok kontrol dan perlakuan

\begin{tabular}{lcc}
\hline Kelompok & $\begin{array}{c}\text { Kadar LH } \\
(\mathbf{m l U} / \mathbf{m l})\end{array}$ & P \\
& Mean \pm SD & \\
\hline Kontrol & $0.362 \pm$ & \\
& 0.016 & \\
P1 & $0.243 \pm$ & 0,000 \\
& 0.021 & \\
P2 & $0.266 \pm$ & \\
& 0.013 & \\
P3 & $0.190 \pm$ & \\
& 0.016 & \\
\hline
\end{tabular}

perbedaan yang bermakna ( $p>0,05)$, sedangkan antara P1 dengan P3 dan P2 dengan P3 didapatkan perbedaan yang bermakna $(p<0,05)$.

Berdasarkan hasil tabel 1 dan tabel 3 diatas, jelas adanya efek pemberian MSG dengan ketiga dosis jika dibandingkan dengan kelompok kontrol dimana terjadi penurunan kadar FSH dan LH yang bermakna. Sedangkan pada tabel 3 antara kelompok perlakuan walaupun dengan dosis yang peningkatannya mencapai $50 \%$ tetap tidak memberikan efek penurunan kadar FSH yang bermakna, tapi tetap memperlihatkan adanya penurunan kadar

Dari tabel 3. diperoleh bahwa pemberian MSG dengan dosis 4800 $\mathrm{mg} / \mathrm{kgbb} / \mathrm{hari}, 7200 \mathrm{mg} / \mathrm{kgbb} / \mathrm{hari}$ dan $9600 \mathrm{mg} / \mathrm{kgbb} / \mathrm{hari}$ menunjukkan pengaruh yang bermakna terhadap kontrol dalam penurunan kadar $\mathrm{LH}$ $(\mathrm{p}=0,000)$.

Tabel 4. Hasil Uji Multiple Comparisons terhadap LH

FSH. Pada tabel 4 terlihat adanya penurunan yang beraturan dari kadar LH.

Secara fisiologis hormon hipotalamus akan mengatur kelenjar hipofisis anterior dalam melepaskan hormonnya. Hormon hipotalamus, salah satunya Gonadotropin-releasing hormone $(\mathrm{GnRH})$ dilepaskan dari ujung serabut saraf hipotalamus di sekitar pembuluh kapiler pada sistem hipotalamus-hipofisis didalam tangkai hipofisis dan mencapai lobus anterior lewat sistem portal khusus yang menghubungkan hipotalamus dengan lobus anterior. Hormon GnRH ini dilepas secara pulsasi sehingga memberikan efek yang lebih baik pada sel target jika diberikan secara berkesinambungan. Selanjutnya pelepasan FSH dan $\mathrm{LH}$ dikendalikan oleh konsentrasi GnRH. ${ }^{(9)}$

Glutamat adalah suatu transmiter eksitatori asam amino susunan saraf pusat utama pada mamalia dan berfungsi menghubungkan sebagian besar transmisi sinaptik eksitator di otak, oleh karena itu glutamat disebut juga sebagai neurotransmiter. Glutamat 
disimpan dalam vesikel sinaptik pada neuron. Apabila terjadi kelebihan glutamat dapat menimbulkan kerusakan neuron (neurotoksin). ${ }^{(10)}$

Kerusakan pada neuron hipotalamus, ${ }^{(4)}$ berkurangnya berat hipofisis $^{(7)}$ dan organ endokrin ${ }^{(8)}$ akibat pengaruh MSG tentu akan mempengaruhi pula dalam pelepasan hormon FSH dan LH. Pada penelitian ini belum dapat dipastikan apakah pengaruh MSG hanya pada hipotalamus saja atau pada hipofisis atau kedua kelenjar endokrin tersebut. Untuk ini perlu dibuktikan dengan jalan mengukur kadar GnRH, bila kadarnya masih normal berarti kerusakan pada hipofisis.

Pada pemberian dengan berbagai dosis tidak didapatkan perbedaan penurunan kadar FSH. Hal ini kemungkinan kerusakan akibat dari neurotoksin glutamat telah mendekati maksimal terhadap sel-sel neuron hipotalamus atau hipofisis, sedangkan penurunan kadar LH yang tidak beraturan belum dapat dipastikan penyebabnya.

\section{KESIMPULAN}

Dari hasil penelitian ini dapat disimpulkan bahwa pemberian MSG dengan dosis sebesar 4800 $\mathrm{mg} / \mathrm{kgbb} / \mathrm{hari}, 7200 \mathrm{mg} / \mathrm{kgbb} / \mathrm{hari}$ dan $9600 \mathrm{mg} / \mathrm{kgbb} / \mathrm{hari}$ terhadap tikus jantan dapat menurunkan kadar FSH dan LH. Makin besar dosis yang diberikan makin besar pula efeknya dalam penurunan kadar FSH dan LH. Disarankan untuk dilakukan penelitian lanjutan untuk mendapatkan dosis minimal yang telah dapat memberikan perubahan kadar FSH dan LH serta pemeriksaan hormon GnRH.

\section{KEPUSTAKAAN}

1. Cogan RH, Toriik, Kare M. ;1979. Biochemical Studies of Glutamate Taste Reseptor: The
Synergistie, New York : Raven Press : 1-9.

2. Muhilal WK.; 1986, Keamanan MSG sebagai bahan tambahan makanan, Dalam : Hasil laporan seminar masalah keamanan MSG. Yayasan Lembaga Konsumen Indonesia.

3. Sand, Jordan; 2005. "A Short History of $M S G$ ". Gastronomica 5 (4): pp.38-49.

4. Uke Y.S.; 2008. Efek Toksik Monosodium Glutamat (MSG) pada binatang percobaan. Sutisning, Vol.3. thn II. 306314.

5. Mayes, PA, Murray RK, Granner, DK., Rodwell, VW; 2003. Catabolism of Proteins \& of Amino Acid Nitrogen. Harper's Illustrated Biochemistry. Lange, 26 th edition. 242.

6. Walker HW, Cheng J ; 2005. "FSH and Testosterone signaling in Sertoli cells", Reproduction 130 (1): 15-28.

7. Pizzi, WJ, Barnhart JE ; 1976. Effect of MSG on Somatic Development, Obesity and Activity in the Mouse. Pharmacol Biochem Behav.551557.

8. Takashi, YU, Shi. W; Ma.R; Yu.I.; 1997. Effect of material Oral Administration in Monosodium Glutamate at a Late Stage of Pregnancy on Developing Fetal Brains. Brain Res., Feb 7, 747 (2) 195-206 
9. Mayes, PA,Murray RK, Granner, DK.,Rodwell,VW; 2000. Hormon Hipofisis dan Hipotalamus. Harper's Biochemistry. Terjemahan. Lange, 25 th edition. 523

10. Longstaff, A ; 2005. Bios Instant Notes Neuroscience, $2^{\text {nd }}$ Edition. Taylor \& Francis Group. 433-434. 